\title{
The Force Majeure Clause Amid New Normal Covid 19
}

\author{
Hardian Iskandar \\ Fakultas hukum, Universitas Muhammadiyah Gresik, Jl. Sumatera No.101, Gn. Malang, Randuagung, Kec. \\ Kebomas, Kabupaten Gresik, Jawa Timur 61121, Indonesia. \\ Corresponding Author Email: hardianiskan@umg.ac.id
}

\begin{abstract}
A force majeure clause is a contractual provision that frees a party to perform a contract due to circumstances that make it impossible to perform the contract. A contract is an agreement made by one or more people. contracts are often made in a written form which contains provisions concerning force majeure. The existence of this clause aims to protect the parties who make the contract from the consequences of a situation where the party cannot perform the contents of the contract. In the new normal era after the COVID-19 pandemic that is currently hitting the impact on the application of contract terms. This study describes the force majeure clause and the considerations when making a new contract in terms of contract law.
\end{abstract}

Keywords: Force Majeure, New normal, Covid-19

\section{INTRODUCTION}

The first case of the transmission of covid-19 occurred in the city of Wuhan China on December 19 which subsequently developed and was named SARS-Cov-2.[1] Currently, any part of the world is inseparable from the COVID-19 pandemic, where the virus has spread widely and is fast spreading. Who itself determines as a pandemic that is often the number of countries that have started contracting the COVID-19 disease.

Now in various countries have implemented Health protocols in various activities carried out outside the room. Which includes using masks, washing hands, and maintaining distance. The impact of this activity cannot be separated from community activities, both in society and in doing business. Which resulted in a decline in the economy, the income of both individuals and companies. Thus, the existence of this pandemic can provide flexibility for debtors not to carry out achievements due to a result of force majeure.

The clause is the content of a written agreement made in an agreement. The contract itself is an agreement that is made and binding for those who make it whereas a force majeure event can be interpreted as an event caused by a greater force, usually in the form of earthquakes, floods, volcanic eruptions, war, riots, government actions, terrorist acts and others. -other parties that prevent the parties from performing in relation to an agreement. Based on this force majeure, the party who did not perform was exempted from compensation because his actions were deemed not as acts of default. Furthermore, this discussion will be examined further regarding the clauses related to force majeure in contracts in the new normal era.

\section{RESULT AND DISCUSSION}

\subsection{The concept of force majeure against} a new disaster event.

Force majeure is a condition in which people are released from an obligation. As the current disaster related to the spread of the COVID-19 virus that has hit has resulted in the emergence of a development of understanding of the operation of a contract that has been agreed both with the imposition of activity restrictions, travel to the closure of an area. The definition of a contract itself is an agreement made by those who make and become a law for those who make the concept of force majeure more stated in an agreed upon agreement where the explanation is specific in the contract. An express clause would normally excuse both delay and a total failure to perform the agreement.[2]

In an event it can be said to be a force majeure, then it can be seen by 1 . Whether the force majeure is stated in the contract agreement made by the parties, 2. Is it possible to commit default, 3. Is an obligation really out of control. So that the main role in taking evidence that it is a force majeure or not, an element of absence of intention to default is needed. Furthermore, the concept of force majeure can be divided into 2 parts, namely the absolute and relative parts.[3]Absolute force majeure can be interpreted as a state of force beyond human power. Furthermore, related to relative force majeure, which is a state of force in which a person cannot perform a contract because that person cannot control their 
soul or is obstructed by the rules of a country. Absolute force majeure is a condition in which the debtor is completely unable to carry out his performance to the creditor, which is due to a situation beyond human ability. for example sunami, floods and volcanic eruptions. Relative force majeure is a condition where the debtor is still possible to fulfill his achievement. For example: an artist when he is going to do a concert today because the artist is sick, the concert is postponed.

Defining a force majeure as a pandemic does not mean that a contract that has been agreed upon can suddenly be said to be a force majeure due to the force majeure itself in terms of a contract or agreement if the contents of the contract do not describe a state of force majeure or a pandemic situation or because of a virus. certain then in proving force majeure because COVID-19 will be difficult to prove. It is different if in a contract there are clauses related to disasters, pandemics or strongly mentioning COVID-19, then to determine the contract is force majeure or cannot be said easily. So it is necessary to pay attention to say a force majeure as the previous explanation, it must be seen loss;

1. There is an effort to reduce the damage or

2. That it is really not possible to carry out the contents of the contract.

However, there are other things that need to be considered related to the counter-force majeure due to COVID-19, if a country applies a rule related to the COVID-19 outbreak which states an emergency of the COVID-19 outbreak in which there are strict sanctions related to violations and in the contents of the regulation obliges all contract activity to be suspended. or suspended until there is further regulation from the government, from here contracts on the basis of force majeure can be applied on the basis of government regulations regarding the COVID-19 emergency.

\section{2. forms of contracts and contracts that do not describe Force Majeure}

Basically, the form of a contract can use two ways, namely making a contract verbally and making a written contract. An oral statement is something that is uttered to another person and agreed by that person to acknowledge a contract. Meanwhile, making a contract is an act in which the party makes a contract in which there are points of agreement which are mutually agreed upon because the assumption that if the statement is not in a written agreement, then the contract agreement does not exist. In making a clausula a contract can be ascertained based on the freedom of contract of the parties making the agreement.[4] Freedom of contract is an agreement made by those who bind themselves in the contract and for the brand to carry out the contents of the contract.[5] However, it should be noted that in Indonesia in this freedom there are basic rules that cannot be violated, among others;

1. Agree between them without any coercion or elements of threat;

2. Able to make an agreement, in this case there are limits on who can make the agreement;

3 . The existence of an object that was agreed upon;

4. Because that is not prohibited in the applicable regulations.

From here it can be found sources, namely from subjective and objective sources. Subjective, namely explaining related persons or legal entities. And objects related to the objects or goods that were promised. Subjective conditions are conditions which emphasize on the person or the legal subject itself if this condition is violated, it can be said that the contract is void. For example, making agreements with threats. Meanwhile, according to the object, an agreement can be said automatically cancelled if the agreement is about the object of prohibited goods.

A contract may be defined as an exchange relationship created by oral or written agreement before two or more persons, containing at least one promise and recognized in law as enforceable. The essential elements of a contract thus include: an oral or written agreement; the involvement of two or more persons; an exchange relationship; at least one promise; and enforceability.[6] Based on the explanation above, it can be interpreted that whatever is made in the agreement by a fundamental legal subject on the principle of freedom of contract. Related to the rise of the COVID-19 pandemic, it can be interpreted that in an agreement that does not state what if a force majeure occurs, steps that can be taken include: 1.Based on freedom of contract, the two parties agree that the COVID-19 pandemic is a force majeure so they can postpone implementation of the contract, renewing or cancelling the contract (negotiation), Contract negotiations are known to not be against good faith. The definitions of good faith include: (a) all parties are free to negotiate with the organization (b) Good intentions must not be carried out with bad intentions, trickery or actions that are contrary to the rules. (c) contrary to good faith, negotiations may be cancelled. 
2.With the issuance of a government regulation stating that COVID-19 is a pandemic. From the explanation above, it can be concluded that there is an agreement between the parties making the contract, and the existence of a government regulation stating an outbreak, in this case COVID19 , the contract can be postponed with an agreement and government authority as the basis for the formation of force majeure. for example, the country of Indonesia has officially designated COVID-19 as a national disaster. This determination was stated in the Presidential Decree (Keppres) of the Republic of Indonesia Number 12 of 2020 concerning the Determination of Non-Natural Disasters for the Spread of 2019 covid-19 as a National Disaster. With this stipulation, the contract that has been made can be said as a force majeure.

\subsection{Contract Clauses in the New Normal Era}

Making a counter clause is essentially inseparable from the basis of freedom of contract, but during the spread of this pandemic, breakthroughs need to occur or things that need to be considered in making the contract itself so that there is no failure to fulfill an achievement. Indeed, it cannot be denied that the completion of the COVID19 pandemic will occur, but a breakthrough must be made with contracts so that existing contracts do not stop or cancel and result in losses in various sectors. So that in the worst case, what needs to be done is the use of the digital world and digital communication tools for making contracts and making contracts. The making of an agreement on a contract must include at least several things in the contract. According to the authors, what must be in the contents of the contract include:

1. The parties to the contract, or the position of each party in this case lies in the position of a person being a creditor or being a debtor.

2. there is an object being agreed upon, a strict sentence with the object which promised, in this case it does not contradict government regulations.

3. time limit of the contract. The time limit for carrying out a contract or it can be interpreted as the end of the contract. For example, a building contract that has been agreed upon is completed in 2 years.

4. regulations regarding default or broken promises, here there are statements involving parties who do not carry out the contents of the agreement.
5. explanation relating to force majeure, the truth in the contract, what are the things that cause an agreement to be unable to be implemented in certain circumstances.

6. With regard to dispute resolution, the reality that occurs in default or is not fulfilled a contract, the party making the agreement may use the negotiation method, arbitration or court in the appropriate jurisdiction.

7. the hands of the parties who make the contract, at the end of the contract is signed by the parties who make the contract which indicates that they agree to the contract.

One of the advantages in a contract is a situation where there is room for the parties to the contract to choose the terms made by those who agree in a contractual. In principle, an agreement cannot be made based on the things stipulated in the contract. In the rights of the parties to change the contents of the contract, the contract must be stated in the contents of the contract itself in relation to the agreed changes. if the callusul is not explained in terms of circumstances that are not possible or force majeure, it will affect the execution of the contract which can bring against the parties who agreed.[7] In the development of the Covid-19 era, we can also see the structure of contracts, among others, we can see from contracts made based on the state and private contracts. From these two things, what defines a state contract is a rule that is usually made by the government with private parties or state-owned entities. In this case, contracts made by the state usually make regulations related to rules or regulations made such as contracts made during the pandemic which are prohibited in an insurance company or financial institution for delinquency in debtor fees, this is a form of state contract rules set forth in the regulations. The government regulation applies to all communities in the region.[8] Anything related to majeur power in the state contract clause is stated in the form of an agreement between any institutions that can create a force majeure based on international agreements or national institutions that make certain conditions force majeure or not. Furthermore, in private matters, the definition of a contract is that the individual is the clarity of an agreement that is released by a legal subject, either a person or a legal entity. Where the existence of force majeure can be seen from the standard contract made, whether there are arrangements or not. Of the two contracts above, the one that plays an important role in terminating a contract is said to be force 
majeure or not, the role of government because the government is in control of a regulation that applies in a country. So that a contract that is made or has been made that does not explain force majeure, as well as government policies, natural disasters that are included in an automatic condition of a contract that does not include rules regulated by the government which are carried out privately can be canceled or can be postponed.

Furthermore, related to contract enforcement and implementation, not only discussing the existence of a contract implementation but giving a sanction if a party does not enter into an agreement,[9] for example A buys a car to $\mathrm{B}$ but at a determined price then $\mathrm{B}$ unilaterally sells to $\mathrm{C}$ so that there is no agreement, in this example what can be done?. From the above example, it is true that the essence of an engagement is freedom of contract, but it needs to be seen from the main thing is about good faith. Good intention is a civil callusul applied in civil law where the person in question has fair and honest ethics or behavior in a contract.[10] So that in this pandemic period, it is also necessary to pay attention to the things that have been explained above further in the drafting contract which must also be considered, namely the preparation of writing the draft correctly, use clear language, in every contract there must be actions that are carried out, after receipt things that are ambiguous in the contract, after that polish the contract clauses that will be made, and it is necessary to also pay attention to consultation with people who are more skilled in the contract.[11]. However, in my opinion apart from the several things above, it must also be considered, among others: a.Contents of the contract Based on the validity of a contract, the contents of the contract are released to the parties who agree on the content or object that was agreed upon, it is prohibited, so it is seen through the law or government regulation, b.Force majeure In relation to this, a contract clause is required to have an explanation regarding the conditions of the force majeure, whether the condition of the force major which is ongoing during the current pandemic or related to the force major that will occur or cannot be predicted. c. Dispute resolution In the explanation of the contract, it is explained that if there is default from one of the parties, the parties who agree can choose which legal route to take to solve the problem among those who have agreed. So that in the current condition of Covid 19, it is not only understanding related to contracts but also understanding from the mental and substance of the contract along with the contract equipment that will be made and also prioritizing governmental concepts that make a regulation of a natural disaster.

\section{CONLUSION}

In the contract clause that contains foce majeur, it needs to be designed and seen from the events said to be foce majeur which resulted in the contract not being able to run properly. so that the efficient way used is to interpret what is said to be a force majeure and what happens when a force majeure occurs. Apart from that, it should be noted that in force majeure, the role of the government can determine a state of force majeure by setting out in government regulations that must be obeyed by parties who have made an agreement, either an agreement made with the government or on a private basis. And further related to the development of pandemic period contract clauses, the priority is that the draft contract made by the parties must be explained to continue a contra or not if the clause does not explain force majeure. And what must also be considered is the readiness of the parties to understand the contracts that are made and signed by the parties.

\section{REFERENCES}

[1] W. H. Sheng, "Coronavirus disease 2019 (covid-19)," J. Intern. Med. Taiwan, vol. 31, no. 2, pp. 61-66, 2020, doi: 10.6314/JIMT.202004_31(2).01.

[2] H. Konarski, "Force Majeure and Hardship Clauses in International Contractual Practice," Int. Bus. Law J., vol. 428, no. 4, pp. 1-21, 2003.

[3] M. D. Badrulzaman, Kompilasi Hukum Perikatan. bandung. Bandung: Citra Aditya Bakti, 2016.

[4] E. M. Weitzenböck, "English Law of Contract : Terms of contract," Univ. I Oslo, no. March, p. 19, 2012.

[5] N. Rules, "Freedom of Contract: and nonmandatory rules of contract law," 2006.

[6] E. Mackaay, "The civil law of contract," Contract Law Econ., no. August, pp. 424453, 2011, doi: $10.4337 / 9781849806640.00028$.

[7] E. Oluwatimilehin, "Covid-19 Possible Effect on Contractual Performance Under," no. May, 2020.

[8] R. A. Epstein, "Toward a Revitalization of the Contract Clause," Univ. Chicago Law Rev., vol. 51, no. 3, p. 703, 1984, doi: $10.2307 / 1599484$.

[9] A. Schwartz and R. E. Scott, "Contract theory and the limits of contract law," Yale 
Law J., vol. 113, no. 3, pp. 541-619, 2003, doi: $10.2307 / 3657531$.

[10] T. Pfeiffer, "Good Faith," ERA Forum, vol. 7, no. 1, pp. 67-75, 2006, doi: 10.1007/s12027-006-0055-3.

[11] S. Williston and F. Pollock, "Principles of Contract," Harv. Law Rev., vol. 35, no. 2, p. 220, 1921, doi: $10.2307 / 1328232$. 